\title{
Vaktaalrubriek
}

\section{Statistiese terminologieprojek}

\author{
H.S. Steyn (jr.) \\ Statistiese Konsultasiediens, Potchefstroomse Universiteit vir Christelike Hoër Onderwys, Privaat sak X6001, \\ Potchefstroom, 2520
}

\section{VERLOOP}

Daar bestaan die afgelope paar dekades 'n Afrikaans-Engelse Statistiekwoordeboek. Hierdie woordeboek is laas in 1984 hersien en ongeveer agt jaar later het die behoefte begin ontstaan om die woordeboek by te werk met byvoeging van nuwe terme en hersiening van die bestaande terme. Aan die einde van 1992 is ' $n$ projek geloods om hierdie werk aan te pak. Die inisiatief is geneem deur die Suid-Afrikaanse Statistiese Vereniging (SASV) se Onderwyskomitee. Die Nasionale Terminologiediens (NTD) het hulp verskaf sover dit advies en infrastruktuur betref. Die SASV moes egter aanvanklik die tydelike redaksionele assistent besoldig. Verder is ' $n$ paneel van medewerkers vanuit akademiese, navorsings- en staatsinstansies benoem. 'n Redaksiekomitee is uit die geledere van die medewerkers aangewys om die projek uit te voer. Tans vergader dié komitee vyf tot ses keer per jaar.

\section{DOEL}

Aanvanklik was die bedoeling om die huidige Statistiekwoordeboek slegs te hersien. Dit het gou duidelik geword dat daar ' $n$ breër behoefte bestaan. Daar is gevoel dat verklaring van terme belangrik is, daarom is begin om elke nuwe term van 'n verbandsin te voorsien. As voorbeeld: random number (simulation; Monte Carlo methods - a number generated at random): ewekansige getal (simulasie; Monte Carlometodes - 'n getal, ewekansig gegenereer).

Hier is dus nie alleen die Afrikaanse vertaling nie, maar ook ' $n$ verbandsin (tussen krulhakies by die Engelse term en tussen ronde hakies aan die Afrikaanse kant). Deel van die verbandsin bevat ook ' $n$ klassifikasie van die veld(e) binne die Statistiek waarbinne die term kan voorkom - in hierdie geval "simulasie" en "Monte Carlo-metodes".

Die doel van die projek is dus nie net verskaffing van ekwivalente (vertaling) nie, maar ook om terme in die korrekte konteks te plaas. Dit is nodig geag omdat die volgende gebruikers vir die voltooide termlys (woordeboek) in gedagte gehou word:

- statistici (akademies en in die praktyk);

- studente wat Statistiek as vak neem;

- navorsers uit ander dissiplines wat Statistiek gebruik;

- vertalers.

Veral met die laaste twee kategorieè in gedagte, is 'n blote Afrikaans-Engelse woordeboek nie toereikend nie.

' $n$ Verdere doel is om die terme op te neem in die NTD se Nasionale Termbank. Statistiese terme word sodoende direk daarin opgeneem in ' $n$ formaat wat in ooreenstemming met hulle vereiste is

\section{WERKSWYSE}

Die redaksiekomitee het met die verloop van tyd ' $n$ vaste werkswyse gevestig. Eerstens voorsien die redaksionele assistent elke lid van ' $n$ werkslys wat bestaan uit ' $n$ Engelse term met ' $n$ voorgestelde Afrikaanse ekwivalent asook die bron waaruit dit kom. Elke lid kry die verantwoordelikheid om sowat dertig terme voor te berei vir bespreking by die vergadering. Hierdie voorbereiding behels die naslaan van die bron en ' $n$ voorstel vir 'n verbandsin en klassifikasie van die term. Daar word ook oorweeg of die term behou moet word en of die ekwivalent sinvol en lewensvatbaar is.

Tweedens word die terme by die redaksievergadering term vir term bespreek. Die bespreekte terme word dan in 'n notule opgeneem wat deur die redaksionele assistent gehou word. Hierdie notule word na die vergadering ook aan alle medewerkers gestuur vir hulle kommentaar.

In die derde plek word die terugontvangde kommentaar weer deur die redaksie bespreek en eers dan word ' $n$ term gefinaliseer en weer genotuleer. Al die afgehandelde notules bevat nou die lys van terme wat ook elektronies beskikbaar is.

Kommunikasie geskied nog meesal per pos, hoewel oorskakeling na E-pos al deels in werking is.

\section{VORDERING}

Tot dusver is net aan nuwe terme aandag gegee. Sowat 1000 terme behoort teen einde 1996 afgehandel te wees wat meesal bestaan uit terme wat met die letters $A$ tot $P$ begin. As gevolg van die bywerk van verbandsinne is die vordering nie so vinnig nie en word 70 - 80 terme per vergadering bespreek. Daar is reeds twee jaar gelede ' $n$ voorlopige lys van afgehandelde terme onder lede van die SASV versprei en dieselfde word vir hierdie jaar beoog.

\section{REDAKSIE}

Die huidige redaksiekomitee bestaan uit:

Prof. H.S. Steyn (jr.), PU vir CHO (Voorsitter)

Prof. C.F. Smit, UP

Mnr. J.P. Lynch, voorheen Sentrale Statistiekdiens

Mev. C.A.P. Vorster, UNISA

Mev. D. Swiegers, NTD (redaksionele assistent).

Waar die redaksionele assistent vroeër die werk tydelik gedoen het en deur die SASV en met behulp van donasies besoldig is, is sy tans voltyds in die NTD se diens met opdrag om onder andere mee te werk aan hierdie projek. Mev. J.M. Steyn van NTD was voorheen ook in 'n adviserende hoedanigheid by die projek betrokke. Hierdie hulp in die vorm van advies, assistensie en infrastruktuur word met groot dankbaarheid deur die statistiese gemeenskap erken. 


\title{
Lesers se kommentaar op voorgestelde chemieterme
}

\author{
W. van Z. de Villiers
}

Departement Stralingstegnologie, Atoomenergiekorporasie, Posbus 582, Pretoria, 0001

'n Vorige bydrae in hierdie rubriek, wat grootliks oor nuwe chemieverwante terme gehandel het,' het heelwat reaksie van lesers uitgelok. Terugvoer oor die terme wat daarin bespreek is, asook vrae en voorstelle met betrekking tot nuwe terme, is nie net van chemici ontvang nie, maar ook van fisici, geoloë en geneeskundiges. Dit is hopelik 'n illustrasie van die wil onder Afrikaanssprekende wetenskaplikes om, veral in die huidige tye waarin Afrikaans dikwels onder groot druk verkeer, steeds die vaktaal uit te bou en te bevorder. Dit is ook wenslik om terme waarvan die gebruik nie tot ' $n$ eng vakgebied beperk is nie, deur gebruikers uit verskillende dissiplines te laat beoordeel.

Lesers se kommentaar, soos weerspieël in ingevulde vraelyste wat ontvang is, word hieronder bespreek. Waar algemene konsensus verkry is oor inskrywings bykomend tot dié wat in die Nuwe Chemiewoordeboek verskyn, word dit in die Nasionale Termbank by die Nasionale Terminologiediens (NTD) opgeneem sodat dit sentraal beskikbaar en maklik toeganklik kan wees.

Die NTD het onlangs die MultiTerm-program uit Duitsland in gebruik geneem om hulle nuwe meertalige terminologiebestuurstelsel te bedryf. Dit is ' $n$ baie gesofistikeerde program en daar is voorsiening gemaak vir ' $n$ wye verskeidenheid inligtingsvelde in die Termbank. Alle relevante inligting (bv. of dit ' $n$ voorkeurterm of verouderde term is, wat die navorsingstatus van die term is, wat die oorsprong van die byvoeging tot die Termbank is) kan volledig by elke rekord aangebring word. Data kan volgens verskeie kriteria onttrek word. By die moontlike toekomstige hersiening van enige woordeboek sal heelwat agtergrondinligting wat deur die samesteller in ag geneem kan word, dus beskikbaar wees. Termbankinligting kan tans per pos, telefoon, faks of E-pos deur enige persoon bekom word." Dit sal hopelik in die toekoms ook op die Internet beskikbaar wees.

\section{Afkortings}

Die afkorting IGP vir induktief gekoppelde plasma (Engels inductively coupled plasma, ICP) is volgens lesers al so wyd ingeburger dat dit vir die doeleindes van vakwoordeboeke naas die meer korrekte IKP aanvaar moet word. By die vorming van afkortings van nuwe terme waarin voltooide deelwoorde gebruik word, behoort egter steeds daarna gestreef te word om liewer die stamwerkwoord in die afkorting te weerspieël.

Die volgende afkortings vir analitiese tegnieke is nou in die Termbank opgeneem:

AAS (atoomabsorpsiespektrometrie) : AAS, atomic absorption spectrometry

AES (Auger-elektronspektroskopie) : AES, Auger electron spectroscopy

AFS (atoomfluoressensiespektrometrie) : AFS, atomic fluoressence spectrometry

ETA (elektrotermiese atomisering) : ETA, electrothermal atomisation

OES (optiese-emissiespektrometrie) <voorkeurterm>, AES (atoomemissiespektrometrie) : OES, optical emission spectrometry <preferred>, AES, atomic emission spectrometry
Let daarop dat voorkeur deesdae gegee word aan die term optiese-emissiespektrometrie in plaas van atoomemissiespektrometrie.

Die term vir die volgende algemeen gebruikte statistiese maatstaf wat tydens dataverwerking in analitiese chemie gebruik word, word so opgeneem:

RSA (relatiewe standaardafwyking) : RSD, relative standard deviation

By die terme dele per miljoen (dpm) en dele per biljoen (dpb), en hul Engelse ekwivalente, word aangedui dat die gebruik daarvan nie aanbeveel word nie. Spesifieke eenhede soos milligram per kilogram $(\mathrm{mg} / \mathrm{kg})$ of milligram per liter $(\mathrm{mg} /)$, wat geen onduidelikheid in die betrokke geval laat nie, moet eerder gebruik word.

\section{Voorgestelde wysigings van inskrywings in die Nuwe Chemiewoordeboek}

In die Nuwe Chemiewoordeboek is die terme standard conditions en normal conditions as sinonieme opgeneem met normale toestande as die ekwivalent in Afrikaans. Daar word voorgestel dat aangedui word dat die gebruik van normal conditions nie aanvaarbaar is nie deur dit te etiketteer as deprecated en die gebruiker na standard conditions te verwys:

normal conditions < deprecated see standard conditions> standard conditions : standaardtoestande

Daar was konsensus onder lesers dat die bestaande inskrywings van

permeate : deurtrek, deurvloei

en die gepaardgaande afleidings van permeate, aangevul moet word met afleidings van permeëer as sinonieme. Die selfstandige naamwoord permeaat moet ook ingesluit word.

Op soortgelyke wyse word verstuif, verstuiwer, ens. as sinonieme gevoeg by

nebulise : vernewel

nebuliser : vernewelaar

ensovoorts.

('n Fout het by die volgende inskrywing in die Nuwe Chemiewoordeboek ingesluip:

perfluorinated carbon : geperfluoreerde koolwaterstof.

Dit moet natuurlik perfluorinated hydrocarbon wees.)

\section{Byvoeging van nuwe terme}

Lesers het saamgestem dat die volgende inskrywings opgeneem behoort te word: 
torch : brander

ICP torch : IGP-brander, IKP-brander

plasma torch : plasmabrander

Oor die Afrikaans vir wrap in die konteks van fibre glass wrapping sal daar nog gepraat moet word. Naas die voorgestelde oorwen is verskeie terme deur lesers verkies, byvoorbeeld (om)wikkel, omwen, omhul, toewikkel en toedraai.

\section{Slot}

Baie dankie aan die lesers wat vraelyste teruggestuur en kommentaar gelewer het. Alle belangstellendes word weereens uitgenooi om vrae en voorstelle met betrekking tot nuwe natuurwetenskaplike terminologie in te stuur sodat dit deur middel van hierdie rubriek vir bespreking oopgestel kan word. Mev. Christine Marais en kollegas by die NTD word bedank vir hul vriendelike hulp en ondersteuning.

\section{LITERATUURWERWYSING}

1. De Villiers, W. van Z. (1996). Nuwe terme in chemie en verwante gebiede, S.Afr. Tydskr. Natuurwet. en Tegnol., 15, 35.

- Nasionale Terminologiediens, Privaat sak X894, Pretoria, 0001

Tel. (012) 314-6160, 314-6153

Faks. (012) $325-4943$

E-pos vt21@acts2.pwv.gov.za vt17@acts2.pwv.gov.za 